\title{
Experimental Study of High Wind Sea Surface Drag Coefficient
}

\author{
I.A. Repina, A.Yu. Artamonov, M.I. Varentsov, A.V. Kozyrev
}

A.M. Obukhov Institute of Atmospheric Physics RAS, Moscow, Russian Federation

\begin{abstract}
Insufficient knowledge of the atmosphere layer structure and momentum, heat and moisture exchange between the rough water surface and atmosphere under various background conditions is currently the main obstacle to the proper functioning of the global and regional weather prediction models and models of climate change. The sea surface drag coefficient is one of the main characteristics of the air-sea interaction, included in the wind waves and sea wind prediction models. In this paper the sea surface drag coefficient under differ condition in the coastal zone and deep sea was estimated from experimental measurements. The shipboard experimental data confirmed that the drag coefficient levels off as wind speed increases under high wind conditions (wind speed greater $25 \mathrm{~m} / \mathrm{s}$ ) while decreases as wind speed further increases. The characters of air-sea interaction in the coastal zone were investigated. It was documented grater drag coefficient under off-shore wind directions offshore documented greater wind stress that could explain of the gusty of coastal winds, shoaling waves and development of internal boundary layers with off-shore flow. Also observed Drag coefficient at on-shore wind are greater than deep water values. It is explained that the wind wave state may be related to bottom topography, coastal line and fetch limited condition. Since the deep water surface drag coefficient is likely to underestimate wind stress and thus storm surge near the coast.
\end{abstract}

Key words: air-sea interaction, strong winds, drag coefficient, off-shore wind

DOI: 10.22449/1573-160X-2015-1-49-58

(C) 2015, I.A. Repina, A.Yu. Artamonov, M.I. Varentsov, A.V. Kozyrev

(C) 2015, Physical Oceanography

Introduction. Lack of knowledge of the off-shore atmosphere layer structure and momentum, heat and moisture exchange with the rough water surface under different conditions is currently the main obstacle to the proper functioning of the operative, global and regional weather prediction models and expert models of climate change. One of the major characters of air-sea interaction, included in the forecast model of wind waves and wind over the sea, is a surface drag coefficient

$$
C_{D}=\frac{\tau_{\text {turb }}}{\rho_{a} U_{10}^{2}}=\frac{u_{*}^{2}}{U_{10}^{2}},
$$

where $U_{10}$ - wind speed at the standard height $H=10 \mathrm{~m} ; \tau_{\text {turb }}(\eta)=\rho_{a} u_{*}^{2}-$ tangential turbulent stress or momentum flux; $\rho_{a}-$ air density; $u_{*}-$ friction velocity. Opinions of various authors on the relation nature of the $C_{D}$ from the mean wind speed are different from each other. Generally, this relationship is represented in two ways: $C_{D}=a+b u_{10}$ or $C_{D}=c u_{10}^{k}$, while values of the coefficients $a, b, c, k$ are significantly different in these articles. See the following relations as the examples:

$$
C_{D}=10^{-3}\left(0,75+0,067 U_{10}\right)-\text { from [1], }
$$




$$
\begin{aligned}
& C_{D}=10^{-3}\left\{\begin{array}{l}
1,24 \mathrm{~m} / \mathrm{c}<U_{10}<11 \mathrm{~m} / \mathrm{s} \\
\left(0,49+0,065 U_{10}\right) 11 \mathrm{~m} / \mathrm{s}<U_{10}<25 \mathrm{~m} / \mathrm{s}
\end{array}-\right.\text { from [2], } \\
& C_{D}=10^{-3}\left(0,87+0,0752 U_{10}-0,000661 U_{10}^{2}\right)-\text { from [3]. }
\end{aligned}
$$

Drag coefficient is determined not only by wind speed but also many other parameters (stratification, wave age, wind direction in the coastal areas, sea depth, precipitation, humidity, etc.), that is the significant differences in parameterization [4] are associated with. Reliable estimations of $C_{D}$ under wind velocities over $5 \mathrm{~m} / \mathrm{s}$ and below $25 \mathrm{~m} / \mathrm{s}$ vary within $1 \cdot 10^{-3}-2 \cdot 10^{-3}$, while drag coefficient increases with the wind speed increase $(<25 \mathrm{~m} / \mathrm{s})$. Stratification effect on $C_{D}$ is particularly evident under gentle breeze. Unstable stratification contributes to its increase, and the stronger it is, the weaker the wind is [5]. Under stable stratification the surface drag, on the contrary, decreases.

Drag coefficient under strong winds. Sea surface drag coefficient is a critical parameter in the theory of hurricanes. Thus, according to the model [6], the characters of a tropical cyclone are mainly determined by the balance of energy entering the atmosphere from the ocean, and the work of the tangential wind stress. Traditional bulk formulas derived on the basis of generalization of the experimental data obtained at wind velocities below $30 \mathrm{~m} / \mathrm{s}$ give higher values of sea surface drag coefficient under hurricanes. Herein the estimates given in [6], show that the energy dissipation due to friction is too high, in order to explain the observed hurricane speed under realistic energy sources.

Explanation of the wind speed high values under hurricanes can be provided if sea surface drag coefficient does not increase with the increasing of wind speed. This idea was confirmed in experiments where the wind speed measurements in tropical cyclones were carried out via falling GPS-probes [7].

On the basis of summarizing the results of these measurements in [8] it was shown that the sea surface drag coefficient decreases when the wind speed exceeds $30-35 \mathrm{~m} / \mathrm{s}$. A similar effect was observed during in situ experiments [9], where it was found that at wind velocities above $25-30 \mathrm{~m} / \mathrm{s}$ the sea surface drag coefficient tends to a constant value, approximately equal to 0.0023 .

The explanation for this phenomenon is devoted a considerable amount of works. The principal approach is based on the effect of splashes, formed during disrupting the crests of steep waves by wind. In [10] the effect of splashes on the exchange of momentum is taken into account and in [11 - 13] a model of sea surface drag reduction by decreasing the turbulent velocity fluctuations in the air layer above the water is developed. In [11] the calculation of the roughness parameter is conducted taking into account the effect of splashes generated by the wave breaking. It is shown that in this case the drag coefficient begins to decrease with increasing wind speed. In [14] a numerical experiment using a joint windwave and atmospheric model was carried out. It is shown that the calculated drag coefficient is consistent with the coefficient obtained from the results of observations.

Such wind strengthening mechanism in the presence of suspended particles is described in $[15,16]$ for sandstorms and $[13,17]$ - for snowstorms. These 
phenomena are united by the fact that in all the cases, the strengthening of the wind speed at the surface the moving layer of the particles (water drops, particles of sand and soil, snowflakes) is formed. That is, the flow becomes two-phase. At the surface the concentration of particles is greater than in the upper layers. This means that in the bottom the density of air mixture (the air and particles) is greater than the above one, i. e. the stable atmosphere density stratification is formed additionally to the temperature one. The more stable stratification is, the more energy is spent by turbulent eddies to overcome buoyancy forces and therefore, the less it becomes, the less mixing intensity is.

In [18] the airflow acceleration effect is due to a change in the geometry of the surface: at a certain stage of rough water development in storm conditions the waves become flatter. A similar result was obtained in [19] applying the joint WRF-wind-wave model.

Drag coefficient experimental determination. For obvious reasons, there is insufficient amount of the direct measurements of the drag coefficient under strong wind conditions. Existing estimates are mainly performed in laboratory. The experiment described in [7], where measurements were taken from airplanes using GPS-falling probe, remains practically the only one. Therefore, any experimental evidence of this effect it is important. Micrometeorological measurement in the atmosphere off-shore flow during the strong winds was carried out in September October 2007 in the Kara Sea on board H/V Victor Buynitsky within the framework of AVLAP/NABOS Russian-American expedition [20]. In October $1-3$ period the vessel was in the area of the Polar Low with wind velocities of $28-30 \mathrm{~m} / \mathrm{s}$.

Drag coefficient was calculated under the formula (1) based on the $10 \mathrm{~m}$ above sea level measurements. To determine the frictional velocity the eddy covariation (EC) method using micrometeorological measurements was applied [21]. Fluctuations of the meteorological parameters were measured by sonic anemometer. The frictional velocity was determined by measuring the three components of the wind speed at $10 \mathrm{~Hz}$ by the formula

$$
\tau=-\rho c_{0}\left[i \overline{u^{\prime} w^{\prime}}+j \overline{v^{\prime} w^{\prime}}\right]=\rho c_{0} u_{*}^{2},
$$

where $u^{\prime}, v^{\prime}, w^{\prime}$ - fluctuations of the three wind speed components: longitudinal (along the wind), transverse and vertical, respectively. Before using the formula (2), the signals were subjected to the primary processing and appropriate corrections needed to apply the method of the pulsation (removal of the emissions and trend, anemometer tilt and frequency characteristic correction, etc.) [22].

Supplying information on the mean wind speed, METEK Sonic Anemometer and AANDERAA automatic weather station installed on a vertical mast at the bow, according the calculations in [23], suit best for micrometeorological measurements on board a moving vessel. $10 \mathrm{~m}$ height of the measurements on small size vessel was sufficient to minimize its impact. To filter the disturbances introduced in the wind speed by the vessel movement, the data consisting of sensors measuring the speed of angular rotation on three axes in the vessel plane and the ternary accelerometer were used [24]. In such a system the actual velocity vector can be written as

$$
\mathbf{U}_{\text {true }}=\mathbf{T}\left(\mathbf{U}_{\text {obs }}+\boldsymbol{\Omega}_{\text {obs }} \cdot \mathbf{R}\right)+\mathbf{V}_{\text {mot }},
$$

PHYSICAL OCEANOGRAPHY NO. 1 (2015) 
where $\boldsymbol{\Omega}_{\mathrm{obs}}$ - angle velocity measured vector; $\mathbf{T}$ - the transition matrix from the vessel coordinates to a true coordinate system; $\mathbf{V}_{\text {mot }}-$ the velocity vector of vessel movement in relation to the water; $\mathbf{R}$ - the distance between the anemometer and the compensation system.

Inertial-dissipative method [25] is convenient to determine the frictional velocity in the marine environment, as it eliminates the need to measure the vertical wind velocity fluctuations and thus allows the use of mobile bases. There are a number of different assumptions and hypotheses (about the local isotropy, the inertial subinterval existence, the assumption of the smallness of the divergence of the vertical transport and stationary fluctuations of external conditions, etc.) in the root of the aforementioned method. On the one hand, in high winds there is no need to take into account the atmosphere stratification when calculating the fluxes, which makes the method easier to perform. But under nonstationarity of the strong winds, presence of a layer of foam and splashes and extra density stratification, this method results in significant errors. Therefore, the preference was given to the EC method.

Data quality analysis was performed using the spectral signal processing, allowing filtering the data, distorted as a result of external impacts (sea water penetration on the sensors, voltage jumps, icing, etc.). As a result, twenty-minute about 40 measurement series with 20 min duration were selected at wind velocities of $20-30 \mathrm{~m} / \mathrm{s}$.

Fig. 1 shows the drag coefficient and wind speed relation obtained after the data processing. The coefficient values were averaged according to the $1 \mathrm{~m} / \mathrm{s}$ intervals of wind velocities. Under the velocities less $20 \mathrm{~m} / \mathrm{s} C_{D}$ increases almost linearly with wind velocity growth. Classical straight line parameterizing this increase [1], is demonstrated in Fig. 1. Variation in the $C_{D}$ values under the given wind velocities occurs due to the influence of wave age [26, 27] and the appearance of ripples [28, 29]. Ripples can both increase and decrease the drag coefficient depending on its moving direction (towards or against the wind) [30]. The results presented in the graph and the given mean square deviation confirm either a decrease, or the increase of the drag coefficient at high wind velocities. In this case, the coefficient stops growing under the wind velocities about $17-20 \mathrm{~m} / \mathrm{s}$, which is consistent with the data [31], and different from the conclusions in [7 - 9]. Unfortunately, measuring the roughness parameters hasn't been conducted in the experiment, but visual observations confirm the existence of two effects - both the appearance of the splash layer and change of the wave. 


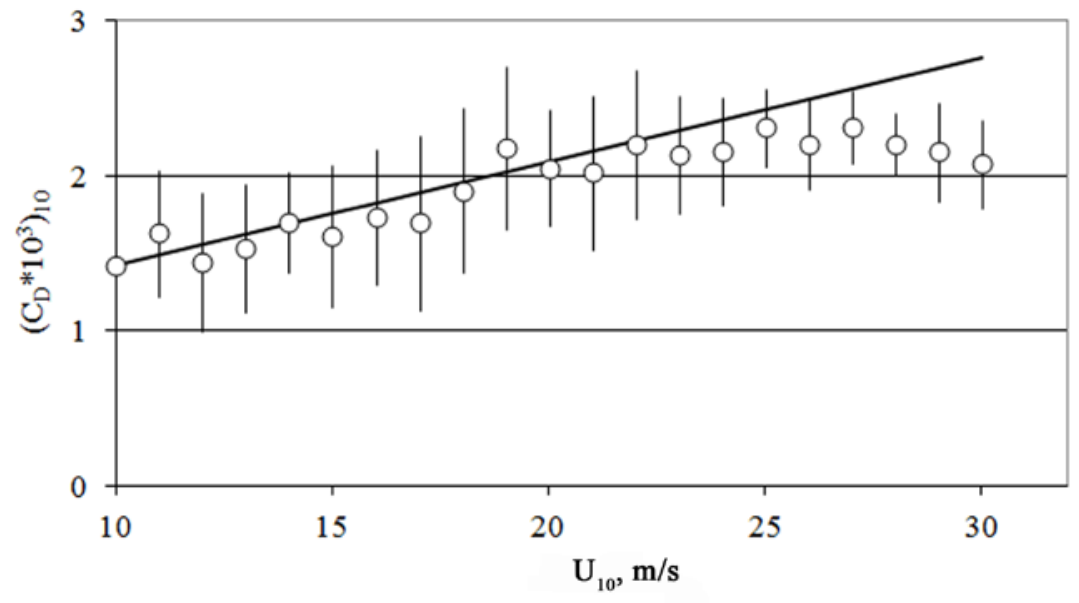

Fig. 1. Relation of the high wind drag coefficient from wind speed according to the measurement data in the Kara Sea (circles - mean values, vertical lines - mean square deviation in $1 \mathrm{~m} / \mathrm{s}$ intervals, straight line - parameterization from [1]

Drag coefficient in the coastal area. The measurements carried out from the stationary platform in the coastal area (based in the MHI Experimental Department in Katsyveli) showed the obtained drag coefficient values to have a great scattering and depend on the wind direction - at the off-shore wind conditions the drag coefficient increases (Fig. 2). In our case we applied the method of pulsation to determine the drag coefficient. The measurements were performed in spring (2005, 2007 and 2012) and autumn (2009, 2011 and 2012) periods that permitted to gather a considerable data array under various background conditions. Particular wind directions for June and September are shown in Fig. 3. For the analysis we used the measurements under the eastern winds when the wave distance could be considered significant and the platform impact was minimized. Gentle and moderate wind data processing is given in [5]. High winds were generally observed from the northern (off-shore winds) and eastern direction. Measurement of the meteoparameter pulsation were carried out at $4 \mathrm{~m}$ height above the sea level at $6 \mathrm{~m}$ bearing in the eastern angle that allowed minimizing the platform impact under operation winds. Mean wind speed was measured at $10 \mathrm{~m}$ height. As it is demonstrated in [5], under moderate and high winds (with speed over $10 \mathrm{~m} / \mathrm{s}$ ) the effect of stratification on the exchange coefficients cannot be taken into the account. 


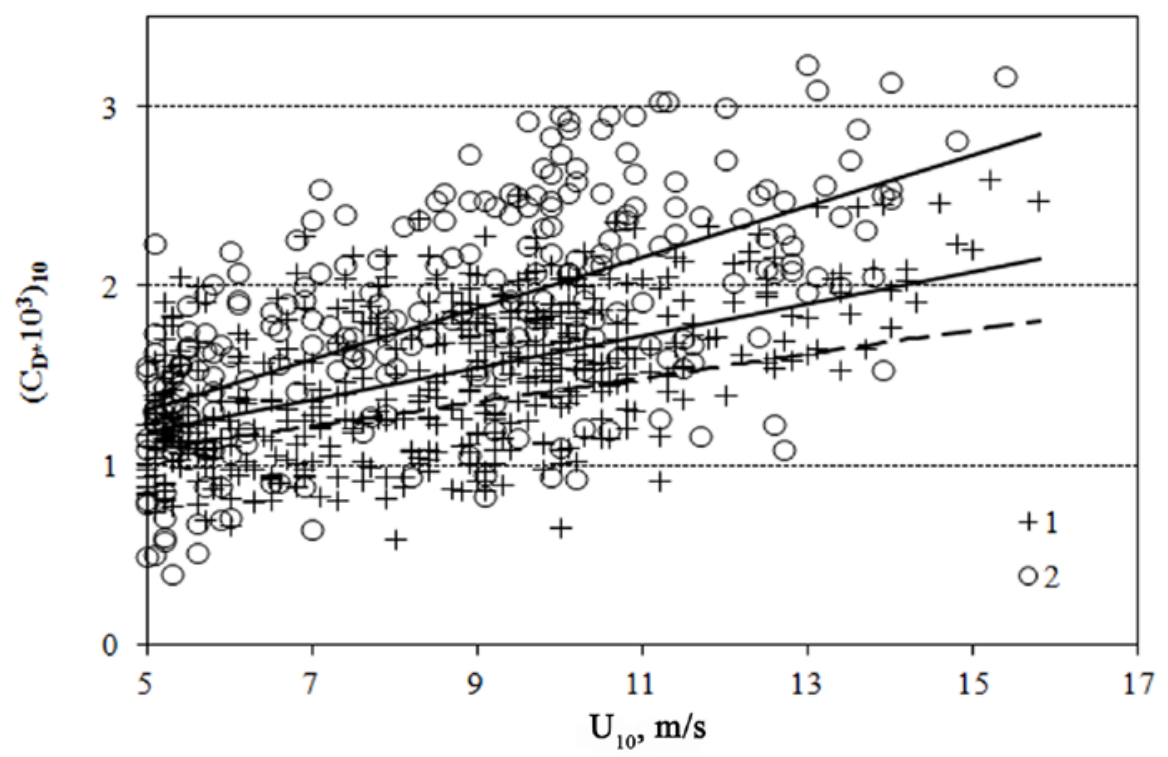

Fig. 2. Relation of sea surface coefficient from the coastal area wind speed according to the pulsation measurement data: 1 - on-shore wind; 2 - off-shore wind (dashed line - parameterization from [1] for the high seas)
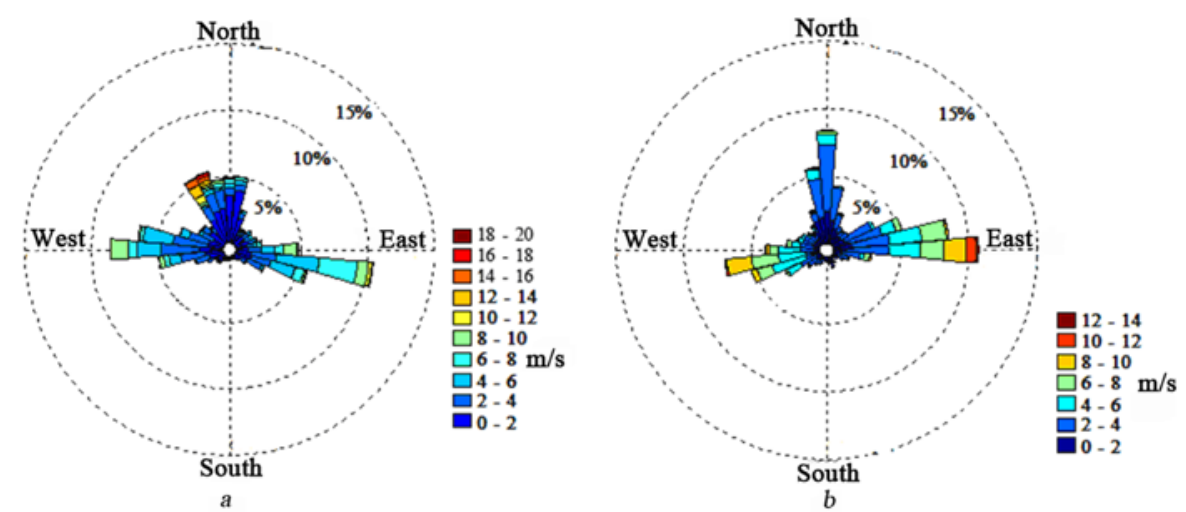

Fig. 3. Wind speed distribution according to the directions in the area of the MHI Experimental Department oceanographic platform (Katsyveli) in June 2012 - a, September $2013-b$

Boundary layer structure in the sea coastal area under off-shore wind conditions depends on different factors: relief and land coastal area roughness elements, wind speed, off-shore distance, stratification and dynamic processes in the atmosphere upper boundary layer [32 - 34]. Under such winds transitional boundary layers are formed over the sea, which are related to inhomogeneity of the geometrical and thermal properties of the surface $[35,36]$. The mean wind speed and turbulence intensity profiles in this case are significantly different from the boundary layer characteristics, typical for open sea conditions or coastal areas with 
flat terrain coastline. At the same time the Monin-Obukhov Similarity Theory application of appears to be difficult. That is the very concept of dynamic speed included in the calculation of the drag coefficient, becomes uncertain, and the value of dynamic speed changes with altitude [37]. The impetuosity of strong onshore winds associated with a significant flow turbulence is also the cause of increase the drag coefficient values.

On-shore wind drag coefficient values are too high in relation to the data obtained in the high seas [1], at that with wind speed increase the difference also increases. This fact was noted before, for example, during the measurements over Lake Ontario in Canada during the transition of waves from deep to shallow water and wind speeds about $14 \mathrm{~m} / \mathrm{s}$ [38], as well as during processing of the data array for the coastal areas exposed to hurricane wind [39].

The main reason for the drag coefficient increase in the coastal area is different characteristics of sea roughness in the deep and shallow water. The effect of wave age on the drag coefficient increase is especially noticeable at low acceleration, typical for coastal areas and enclosed seas. [27] The dependence of the drag coefficient on the wave age can be caused by two factors: developing waves move at the lower phase velocity with respect to the wind, and thus contribute to a certain braking of the interaction; developing steeper waves, which leads to separation of the flow from the wave crests and the drag increase. Wave steepness also increases when they enter the shallow water. Another aspect of bottom topography impact on the rough surface structure is also well-known - in coastal areas entering the shallow water wave breaking frequency increases [40 - 43]. In laboratory studies $[44,45]$ nearly a doubling of the turbulent wind stress has been found over an area of strong breaking compared with the rough surface, where this wave breaking has just begun. Furthermore, the waves, passing in and out the denting in shallow water, experience refraction, which may lead to an increase in the roughness parameter in the coastal area and movement of waves in different ways [46].

Thus, the following causes of the drag coefficient increase in the coastal (shallow) area can be marked: wave phase velocity decrease; their steepness growth; quickly changing wave field; wave direction in the coastal area cannot coincide with the mean wind direction. All these facts should be taken into consideration in the development of atmosphere-surface interaction parameterizations in coastal areas, especially in storm phenomena forecast [47].

Conclusions. The momentum transfer between the atmosphere and the ocean is in many respects determined by the sea surface roughness. In addition, the momentum flux is affected by the wind speed, atmospheric stratification, the size, the steepness and the phase velocity of the wind waves and swells. In the coastal area the bottom topography, wind direction and the off-shore wind internal boundary layer formation are added to these parameters.

In this article we experimentally confirmed that the high wind drag coefficient decreases with the wind increase. This phenomenon can be explained on the basis of two-phase flow theory, as well as of the effect of wind wave geometry changes. In the coastal area under high onshore winds the high $C_{D}$ values are observed, due to the atmospheric boundary layer structure peculiarities (formation of internal boundary layers) in this area and with gusty onshore winds.

PHYSICAL OCEANOGRAPHY NO. 1 (2015) 
Measurements of the on-shore wind drag coefficient in the coastal area also showed higher values in comparison with the open sea. This is consistent with the assumption of the momentum flux increase over the developing roughness. Also the wave breaking growth in shallow water and other factors associated with bottom topography and nature of the coastline give the contribution to $C_{D}$ increase. Different from the drag coefficient standard dependence nature on the wind speed and bottom topography should be considered in the coastal area in the simulation of storm conditions and hurricanes.

Acknowledgements. The present research was carried out under Russian Science Foundation support, Grant No. 14-27-00134.

\section{REFERENCES}

1. Garratt, J.R., 1977, "Review of Drag Coefficients over Oceans and Continents”, Mon. Weather Rev, vol. 105, pp. 915-929.

2. Large, W.G, Pond, S., 1981, "Open ocean momentum flux measurements in moderate to strong winds”, J. Phys. Oceanogr., no. 11, pp. 324-336.

3. Taylor, P.K., Yelland, M.J., 2001, "The dependence of sea surface roughness on the height and steepness of the waves”, J. Phys. Oceanogr., vol. 31, no.2, pp. 572-590.

4. $\quad$ Repina, I.A., 2000, "Issledovanie dinamicheskikh kharakteristik i temperaturnogo rezhima vodnoy poverkhnosti $v$ Kaspiyskom more [The research of dynamical characteristics and temperature state of the sea surface in the Caspian Sea]”, Meteorologiya i gidrologiya, no. 10, pp. 15-27. (in Russian)

5. Repina, I.A., Artamonov, A.Yu. \& Chukharev, A.M., [et al.], 2012, "Air-Sea interaction under low and moderate winds in the Black Sea coastal zone”, Estonian Journal of Engineering, no. 2, pp. 3-18.

6. Emanuel, K.A., 1955, "Sensitivity of tropical cyclones to surface exchange coefficients and a revised steady-state model incorporating eye dynamics”, J. Atmos. Sci., vol. 52, pp. 39693976.

7. Black, P.G., D’Asaro, E.A. \& Drennan, E.A. [et al.], 2007, “Air-Sea Exchange in Hurricanes Synthesis of Observations from the Coupled Boundary Layer Air-Sea Transfer Experiment", Bulletin of American Meteorological Society, no. 3, pp. 357-374.

8. Powell, M.D., Vickery, P.J. \& Reinhold, T.A., 2003, "Reduced drag coefficient for high wind speeds in tropical cyclones”, Nature, vol. 422, pp. 279-283.

9. Donelan, M.A., Haus, B.K. \& Reul, N. [et al.], 2004, “On the limiting aerodynamic roughness of the ocean in very strong winds”, Geophys. Res. Lett., vol. 31, L18306.

10. Andreas, E.L., 2004, “Spray stress revised”, J. Phys. Oceanogr, vol. 34, pp. 1429-1440.

11. Makin, V.K., 2005, “A note on drag of the sea surface at hurricane winds”, Boundary Layer Meteorol., vol. 115, no.1, pp.169-176.

12. Kudryavtsev, V.N., 2006, “On the effect of sea drops on the atmospheric boundary layer”, $J$ Geophys. Res., vol. 111, C07020.

13. Butner, E.K., 1978, "Dinamika pripoverkhnostnogo sloya vozdukha [Dynamic of surface air layer]”, Leningrad, Hydrometeoizdat, 156 p. (in Russian) 
14. Moon, I.-J., Ginis, I. \& Hara, T., 2004, "Effect of surface waves on air-sea momentum exchange. Part II: Behavior of drag coefficient under tropical cyclones”, J. Atmos. Sci., vol. 61., pp. 2334-2348.

15. Semenov, O.E., 2000, “Ob uskorenii potoka vo vremya sil'nykh peschanykh i pylevykh bur' [Increasing of flux velocity during strong dust and sand storm]”, Gidrometeorologiya i ekologiya, no. 3-4, pp. 15-27. (in Russian)

16. Barenblat, G.I., Golitsyn, G.S., 1974, “Local structure of mature dust storms”, J. Atmos. Sci., vol. 3, no. 7, pp. 1917-1933.

17. Lykossov, V.N., 2001, "Numerical modeling of interaction between the atmospheric boundary layer and the Antarctic ice shelf”, Russ. J. Numer. Anal. Math. Modelling., vol. 16, pp. 315-330.

18. Trotskaya, Yu.I., Rybushkina, G.V., 2008, "Quasi-linear model of interaction of surface waves with strong and hurricane winds”, Izvestiya, Atmospheric and oceanic physics, vol. 44, no. 5, pp. 621-645.

19. Miyamoto, Y., Ishikawa, H., Takemi, T., 2007, "Modeling the air-sea-wave interaction under typhoon conditions: model development and a preliminary result for typhoon ioke", Proceeding at the 8-th WRF users workshop, Boulder, NOAA, pp. 1-13.

20. Polyakov, I.V. [et al.], 2007, "Observational program tracks Arctic Ocean transition to a warmer state”, Eos, Transactions, American Geophysical Union, vol. 88, pp. 398-399.

21. Foken, T., 2008, “Micrometeorology”, Springer, 308 p.

22. Burba, G., 2013, "Eddy Covariance Method for Scientific, Industrial, Agricultural, and Regulatory Applications: A Field Book on Measuring Ecosystem Gas Exchange and Areal Emission Rates”, Lincoln, LI-COR Biosciences, 331 p.

23. Moat, B.I., Yelland, M.J. \& Pascal, R.W., 2006, "Quantifying the airflow distortion over merchant ships. Part 1: Validation of a CFD model”, J. Atmos. Oceanic Technol., vol. 23, pp. 341-350.

24. Edson, J.B., Hinton, A.A. \& Prada, K.E. [et al.], 1998, “Direct Covariance Flux Estimates from Mobile Platforms at sea”, J. Atmos. Oceanic Technol., vol. 15, pp. 547-562.

25. Fairal, C.W., Larsen, S.E., 1986, "Inertial-dissipation method and turbulent fluxes at the airocean interface”, Boundary-Layer Meteorol., vol. 34, pp. 287-301.

26. Kitaigorodskyi, S.A., Volkov, Yu.A., 1965, "O parametre sherokhovatosti morskoy poverkhnosti i raschete turbulentnykh potokov kolichestva dvizheniya $v$ privodnom sloe atmosfery [Roughness parameter of sea surface and calculation of turbulent momentum fluxes in surface atmospheric layer]", Izv. AN SSSR. Fizika atmosfery i okeana, vol. 1, no. 9, pp. 1523 (in Russian).

27. Drennan, W.M., Graber, H.C. \& Hauser, D., [et al.], 2002, "On the wave age dependence of wind stress over pure wind seas”, J. Geophys. Res., vol. 108, C3, 8062, doi:10.1029/2000JC000715.

28. Volkov, Yu.A., 1969, "Spektry pul'satsiy skorosti i temperatury vozdushnogo potoka nad vzvolnovannoy poverkhnost'yu morya [Spectrum of air flux velocity and temperature under wave sea surface]”, Izv. AN SSSR. Fizika atmosfery i okeana, vol. 5, pp. 7-12 (in Russian)

29. Donnelan, M.A., Drennan, W.M. \& Katsaros, K., 1977, "The air-sea momentum flux in conditions of wind sea and swell”, J. Phys. Oceanogr., vol. 27, pp. 2087-2099.

30. Drennan, W.M., Kahma, K.K. \& Donelan, M.A., 1999, "On momentum flux and velocity spectra over waves”, Boundary-Layer Meteorology, vol. 92, no. 3, pp.489-515. 
31. Bye, J.A.T., Jenkins, A.D., 2006, "Drag coefficient reduction at very high wind speeds", $J$. Geophys. Res., vol. 111, C03024, doi:10.1029/2005JC003114.

32. Gao, Z., Wang, Q. \& Zhou, M., 2009, "Wave-dependence of friction velocity, roughness length, and drag coefficient over coastal and open water surfaces by using three databases", Advances in Atmospheric Sciences, vol. 26, no. 5, pp. 887-894.

33. Artamonov, A.Yu., Buchnev, I. A. \& Repina, I.A. [et al.], 2005, “Turbulent Fluxes of Heat and Momentum and Statistical Characteristics of Turbulence in the Near-Surface Air in NearShore and Deep-Water Zones of the Black Sea”, Oceanology, vol. 45, suppl. 1, pp. S27-S38.

34. Soloviev, Yu.P., Ivanov, V.A., 2007, “Predvaritel'nye rezul'taty izmereniy atmosfernoy turbulentnosti nad morem [Preliminary results of measurements of atmospheric turbulence over the sea]”, Morskoy gidrofizicheskiy zhurnal, vol. 17, no. 3, pp. 154-172 (in Russian).

35. Soloviev, Yu.P., 2010, “Harakteristiki vnutrennego pogranichnogo sloya nad morem pri vetre s berega, imeyushchego gornyy rel'ef [Characteristics of internal boundary layer above sea under coastal wind from mountain]", Ekologicheskaya bezopasnost' pribrezhnoy i shel'fovoy zon i kompleksnoe ispol'zovanie resursov shel'fa, vol. 21, pp. 87-74 (in Russian).

36. Soloviev, Yu.P., Kudryavtsev, V.N., 2010, "Wind-Speed Undulations Over Swell: Field Experiment and Interpretation”, Boundary Layer Meteorology, vol. 136, no. 3, pp. 341-363.

37. Ivanov, V.A., Soloviev, Yu.P., 2004, “Metodika i predvaritel'nye rezul'taty izmereniy atmosfernoy turbulentnosti $v$ pribrezhnoy zone Chernogo morya [The Method and preliminary results of the atmospheric turbulence measurements in the Black sea coastal zone]", Ekologicheskaya bezopasnost' pribrezhnoy i shel'fovoy zon i kompleksnoe ispol'zovanie resursov shel'fa, vol. 10, pp. 78-102 (in Russian).

38. Anctil, F., Donelan, M.A., 1996, “Air-water momentum flux observations over shoaling waves”, J. Phys.Oceanogr., vol. 26, pp. 1344-1353.

39. Vickery, P.J., Skerlj, P.F., 2000, “Elimination of exposure D along the hurricane coastline in ASCE 7”, J. Struct. Eng., vol. 26, pp. 545-549.

40. Thornton, E.B., Guza, R.T., 1982, "Energy Saturation and Phase Speeds Measured on a Natural Beach”, J. Geophys. Res., vol. 87, pp. 9499-9508.

41. Holman, R.A., Sallenger, A.H., 1985, "Setup and swash on a natural beach”, J. Geophys. Res., vol. 90, pp. 945-953.

42. Dean, R.G., Dalrymple, R.A., 1991, "Water wave mechanics for engineers and scientists”, Singapore, World Scientific, $368 \mathrm{p}$.

43. Holland, K.T., Raubenheimer, B. \& Guza, R.T., 1995, "Run-up kinematics on a natural beach”, J. Geophys. Res., vol. 100, pp. 4985-4993.

44. Banner, M.L., Melville, W.K., 1976, “On the separation of air flow over water waves”, J. Fluid Mech., vol. 77, pp. 825-842.

45. Kawamura, H., Toba, Y., 1988, "Ordered motion in the turbulent boundary layer over wind waves”, J. Fluid Mech., vol. 197, pp.105-138.

46. Munk, W.H., Traylor, M.A., 1947, "Refraction of ocean waves: a process linking underwater topography to beach erosion”, J. of Geology., vol. 55, pp. 1-26.

47. Westerink, J.J., Feyen, J.C. \& Atkinson, J.H. [et al.], 2008, “A basin to channel scale unstructured grid hurricane storm surge model applied to southern Louisiana”, Mon. Weather Rev., vol. 136, no. 3, pp. 833-864. 